\title{
Using tree-rings to determine large wood residence time and transport pulses in a gravel- bed river
}

\author{
Maxime Boivin ${ }^{1,3^{*}}$, Thomas Buffin-Bélanger ${ }^{2,3}$, and Dominique Arseneault ${ }^{2,3}$ \\ ${ }^{1}$ Département des sciences humaines et sociales. Université du Québec à Chicoutimi. 555, boulevard \\ de l'Université, Chicoutimi (Québec), Canada, G7H 2B1. \\ ${ }^{2}$ Département de Biologie, Chimie et Géographie. Université du Québec à Rimouski. 300 Allée des \\ Ursulines, Rimouski, Québec, Canada, G5L 3A1. \\ ${ }^{3}$ Centre d'étude Nordique, Université Laval et Université du Québec à Rimouski
}

\begin{abstract}
The Saint-Jean River (SRJ) in Eastern Canada is prone to the formation of very large rafts of wood. Managers of the SJR suspected these jams to influence salmon migration and carried out a dismantling operation to remove large wood accumulated in a $1.2 \mathrm{~km}$ long wood raft. This operation became a great opportunity to address key issues relating to large wood dynamics in a fluvial system: residence time and flood contribution to wood recruitment and transport. During the dismantling, we systematically sampled 319 trees from which year of death could be estimated from dendrochronology and year of accumulation in the raft could be obtained from satellite and aerial photos. These two dates allowed us to quantify the residence time for 262 datable large wood (LW) within the fluvial system, to examine the peak years of LW recruitment and to correlate the raft growth rate with hydrometeorological conditions since 1993. The results also emphasized four types of LW flood related to wood dynamics: 1) an erosive flood that produces a large amount of wood in river, 2) a mobilizing flood that carries large quantities of wood, 3) a flood mix that both recruits and transports large quantities of wood, and 4) an ice-breakup flood.
\end{abstract}

\section{Introduction}

Research on large wood (LW) budget in river has multiplied over the last decades providing insightful understandings of most components of LW dynamics. LW residence time in river constitutes a key component still under documented because of the research effort needed to estimate it. LW residence time refers to the time duration from the recruitment of a LW piece to the time it exits a fluvial system. The time a LW remains within a fluvial system is needed to better describe the influence of LW on river habitats and dynamics. Very few studies have examined the variability of the residence time over time and between fluvial systems and the environmental factors that control this variability.

*Corresponding author: maxime2_boivin@uqac.ca 
Studies have shown that the residence time can vary from a few years to several hundred years and even over periods of more than 1400 years [1, 2, 3, 4]. The climate, the type of forests, the size of the LW, their positioning in the system, in situ conditions of the accumulation zones, the geomorphology and the river dynamics have been identified has key variables to explain the wide range of residence time documented $[5,6,7]$.

Few methods have been used to estimate LW residence times in lakes and rivers. Webb and Erskine [8] used radiocarbon techniques, but the method is limited by the uncertainty margin that does not allow to have the exact year of mortality and may prove costly to produce a large distribution of residence time values. Less expensive, tree-ring analyses have been used extensively to document hydrogeomorphological dynamics [9] and large wood dynamics [4]. Hyatt and Naiman [4] use dendrochronological techniques analysis to estimate residence times on 69 conifers datable in the Queets River providing one of the first estimations of residence time values. In this paper, we analyze 262 tree-rings samples extracted from the very large raft of the Saint-Jean River (SJR). The data set allows a unique opportunity to document the variability of LW residence times and to examine the role of environmental factors on large wood recruitment and transport in a fluvial corridor exposed to river ice dynamics.

\section{Methods}

\subsection{The raft of the Saint-Jean River}

The SJR $\left(48^{\circ} 50^{\prime} 03^{\prime \prime} \mathrm{N}, 64^{\circ} 35^{\prime} 20^{\prime \prime} \mathrm{W}\right)$ is located in the eastern part of the Gaspé Peninsula in Québec, Canada (Figure 1A and B). It drains an area of $1130 \mathrm{~km}^{2}$, has an approximate length of $130 \mathrm{~km}$, and an average annual flow of $30 \mathrm{~m}^{3} / \mathrm{s}$. The hydrological regime of the river is characterised by well-defined spring floods. The SJR is a semi-alluvial gravel bed river with succession of meandering, riffle and pools and anastomosed sections. The anastomosed style is essentially found in the delta where overbank deposits of fine sediments and rafts generated avulsions occur frequently (Figure 1C). Previous studies have described the annual and decadal components of the LW wood budget and examined several aspects of the LW dynamics $[10,11,12]$ in the SJR, including the evolution of the large raft from which we sampled trees to estimate their residence time in the watershed.

\subsection{Field methods and sampling}

Managers of the SJR carried out a vast dismantling operation to remove more than 1200 linear meters of the large raft in February 2015 (Figure 1D). Extraction was realized during winter time to minimize the mobilization of sediment but also to facilitate the machinery to operate on river ice cover. We took this opportunity to collect large wood samples for treering analysis along the whole length of the raft. In total, 319 pieces of Thuja occidentalis were extracted from which 262 presented high-quality growth rings that could be used for dendrochronological analysis (Figure 1E). On average, one sample was extracted every 3 linear meters but, because extracting was realized using large machinery in a difficult and moving working environment, the exact position of each large wood was estimated with a precision of between 25 to 50 meters. This accuracy is sufficient to identify the year of arrival in the raft, considering that each major flood brings more than 50 to 200 linear meters of wood in the mouth of the SJR [10]. Figure 1F locates the position of the 262 samples atop the estimated year of accumulation using aerial and satellite images from 1993 to 2013 [12]. The figure shows the large variability of interannual wood 
accumulation. For example, 200 linear meters of wood were accumulated in 2010-2011 whereas no additional wood was accumulated in 2007-2008.

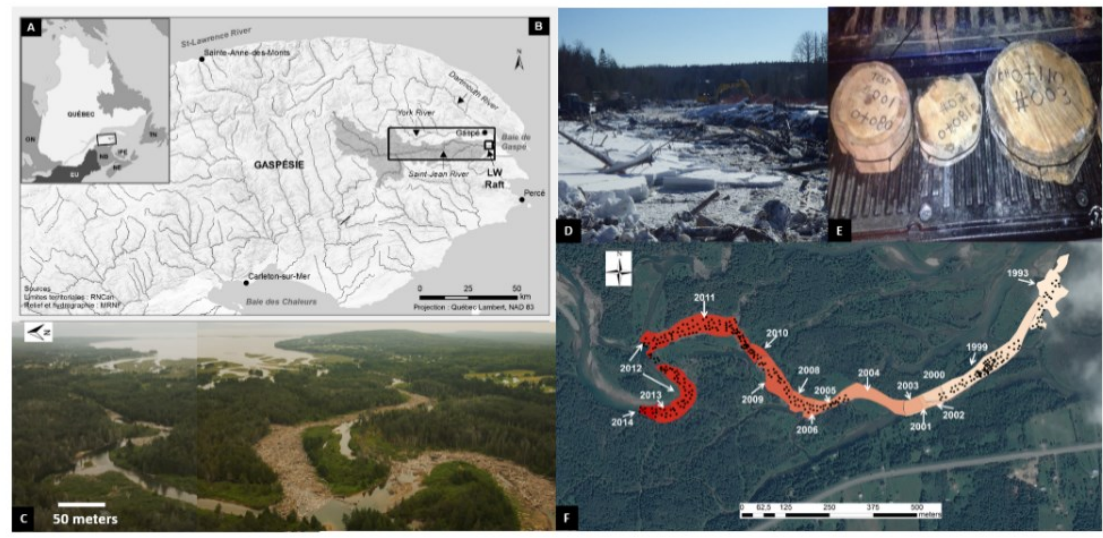

Fig. 1. (A) Large-scale map showing the location of the Saint-Jean River in Québec, Canada; (B) Location of the Saint-Jean River on the Gaspé Peninsula; (C) Aerial view of the Saint-Jean delta in September 2014, just before dismantling; D) Mechanical dismantling of the ice jam in winter 2015; E) Examples of samples collected during dismantling and; F) Aerial view of SJR raft with the evolution of the large wood jam (LWJ) surfaces in the south channels of the Saint-Jean River delta as mapped from aerial and satellite images between 1993 and 2014 (white arrows) and location of each recovered sample (black dots).

\subsection{Crossdating analysis and residence time estimation}

All wood samples were sanded to allow good quality readings of their annual growth. Two measurement paths per sample were digitized at 4800 DPI to measure the width of the annual growth rings using the program CooRecorder 8.1. Samples were then crossdated using PAST5 and the master chronology (1404-1982 AD) developed by Cook [14] along the nearby Sainte-Anne River $\left(47^{\circ} 15^{\prime} 24^{\prime \prime} \mathrm{N}, 71^{\circ} 39^{\prime} 11^{\prime \prime} \mathrm{W}\right)$. Because the surface of samples was smooth and non-eroded, we assumed that the wood recruitment year $\left(\mathrm{Y}_{\mathrm{R}}\right)$ corresponds to the crossdated year of death (i.e. the outermost tree ring). The wood accumulation year $\left(\mathrm{Y}_{\mathrm{A}}\right)$ was determined by analyzing the raft evolution from aerial photos (1993-2004), satellite images (1999-2014) and five years surveys (2010 to 2014) [10,11, 12]. Using these images, it was possible to determine the most probable year that each LW was accumulated within the delta $[10,12]$ based on the extraction location (Figure 1F). Finally, the residence time (RT) (transit from the watershed to the end of the system in the SJR delta) was estimated by subtracting the recruitment year from the accumulation year: RT $=$ $\mathrm{Y}_{\mathrm{A}}-\mathrm{Y}_{\mathrm{R}}$

\subsection{Discharge series analysis}

Discharge series for the SJR are available for the 1995-2006 period. A longer time series (1945-2015) is also available from two gauging stations on the York River, an adjacent watershed with similar length, area, topographic gradient, and estuary dynamics. A linear regression between York River ( $\left.\mathrm{Q}_{\mathrm{YR}}\right)$ and SJR ( $\left.\mathrm{Q}_{\mathrm{SJR}}\right)$ specific daily discharges [15] computed for the 1995-2006 period was used to estimate SJR discharges for the 20062014 period $\left(\mathrm{Q}_{\mathrm{SJR}}=\mathrm{Q}_{\mathrm{YR}}{ }^{*}\left(\mathrm{~A}_{\mathrm{SJR}} / \mathrm{A}_{\mathrm{YR}}\right) 1.12 ; \mathrm{R}^{2}=0.92\right)[10]$. Figure 2 shows the annual hydrograph including the mean, maximum and minimum daily discharge data for the SJR 
between 1966 and 2014. The various floods between 1993 and 2014 are shown according to their type (ice break-up, spring, summer or autumnal events). Multiple floods in a single year (e.g. 2004, 2007) are considered in order to examine their effect on the mobility and production of LW.

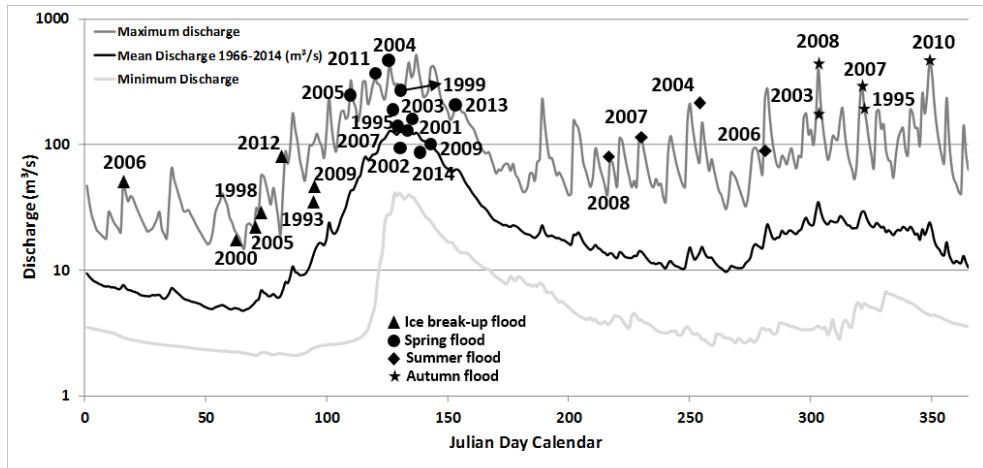

Fig. 2. Annual hydrograph of the SJR including mean, maximum and minimum daily discharge. The various floods that occurred between 1993 and 2014 are indicated.

\section{Results}

\subsection{Characteristics of large wood sampled in the raft}

Figure 3 provides information on the large wood sampled in the raft. More than $90 \%$ of the samples are from three having DBH between 1.6 and $3.3 \mathrm{~m}$ (Fig. 3A). This compares well to DBH measured on LW in the river corridor and on living trees in the alluvial plain [10] The majority of LW pieces accumulated during the periods 1996-1999 and 2008-2014 (Figure 3B). The average and median number of rings for all samples are 139 and 128, respectively. The IQR for the number of rings is 76 while the smallest and largest number are 43 and 344, respectively (Figure 3C). The majority of the LWs died between 1980 and 2013, but some trees had died before 1920 (Figure 3D).
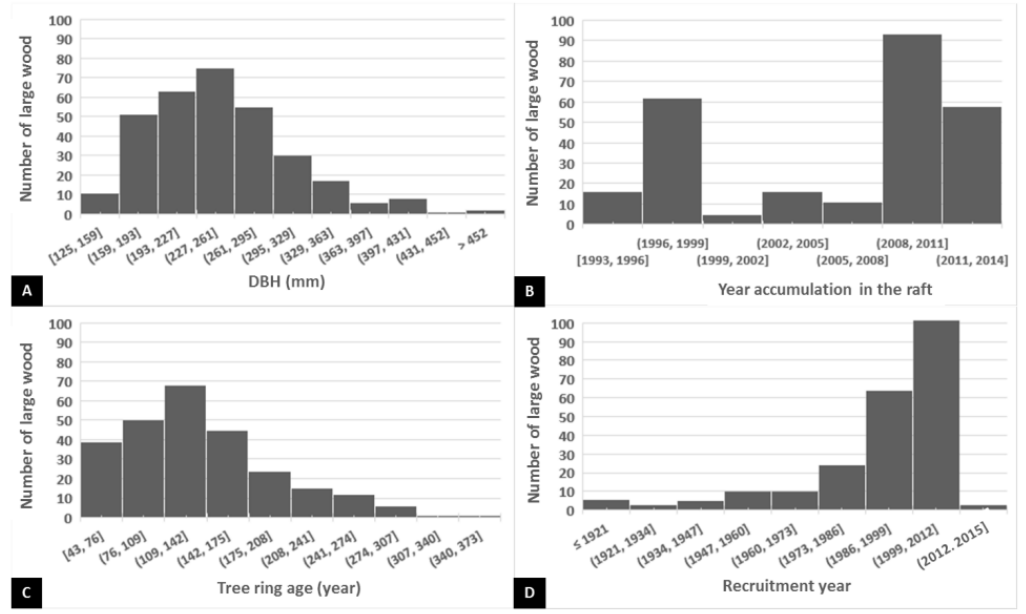

Fig. 3. A) Diameter at breast height for the extracted sampled from the raft; B) the year of accumulation in the raft $\left(\mathrm{Y}_{\mathrm{A}}\right)$; $\left.\mathrm{C}\right)$ the number of rings for all samples and; $\left.\mathrm{D}\right)$ the recruitment year along the river corridor $\left(\mathrm{Y}_{\mathrm{R}}\right)$. 


\subsection{Large wood residence time and temporal pattern of large wood recruitment}

The residence time of the 262 samples is relatively short with an average and a median of 13 and 3 years, respectively (Table 1). Only 3 trees had a residence time longer than 100 years $(\max =172$ years) while 64\% (167 samples) had a residence time shorter than 5 years. It is interesting to observe that the years with significant floods (2010-2011, 2012 and 2013) show a more variable residence times than years with less significant floods. These significant flood events (with and without ice) may have transported some LW pieces away from the active bed. The overall residence time variability is relatively high with interquartile range (IQR) and standard deviation of 11 and 24 years, respectively. The mean residence time is 13 years with an IQR of 12 for 2004; 23 years with an IQR of 16.5 for 2009 and 23 years with an IQR of 45.5 for 2013 .

Table 1. General characteristics of the LW residence time (RT) in the Saint-Jean River raft

\begin{tabular}{cccccccccc}
\hline $\begin{array}{c}\text { Accumulation } \\
\text { year in the SJR } \\
\text { delta }\end{array}$ & $\boldsymbol{n}$ & $\mathbf{\%}$ & Cumulative \% & $\begin{array}{c}\text { Mean } \\
\text { (RT) }\end{array}$ & $\begin{array}{c}\text { Median } \\
\text { (RT) }\end{array}$ & $\begin{array}{c}\text { Min } \\
\text { (RT) }\end{array}$ & $\begin{array}{c}\text { Max } \\
\text { (RT) }\end{array}$ & $\begin{array}{c}\text { IQR } \\
\text { (RT) }\end{array}$ & $\begin{array}{c}\text { Standard } \\
\text { deviation (RT) }\end{array}$ \\
\hline $\mathbf{1 9 9 3}$ & 15 & 6 & 6 & 16 & 10 & 0 & 102 & 8,5 & 25 \\
$\mathbf{1 9 9 4}$ & 1 & 0 & 6 & 0 & 0 & 0 & 0 & 0 & 0 \\
$\mathbf{1 9 9 9}$ & 62 & 24 & 30 & 11 & 4 & 0 & 98 & 13 & 17 \\
$\mathbf{2 0 0 0}$ & 4 & 2 & 31 & 4 & 2 & 0 & 4 & 5 & 5 \\
$\mathbf{2 0 0 1}$ & 1 & 0 & 32 & 0 & 0 & 0 & 0 & 0 & 0 \\
$\mathbf{2 0 0 2}$ & 0 & 0 & 32 & 0 & 0 & 0 & 0 & 0 & 0 \\
$\mathbf{2 0 0 3}$ & 0 & 0 & 32 & 0 & 0 & 0 & 0 & 0 & 0 \\
$\mathbf{2 0 0 4}$ & 4 & 2 & 33 & 13 & 2 & 1 & 46 & 12 & 22 \\
$\mathbf{2 0 0 5}$ & 12 & 5 & 38 & 12 & 2 & 0 & 60 & 10,3 & 20 \\
$\mathbf{2 0 0 6}$ & 6 & 2 & 40 & 17 & 1 & 0 & 94 & 2,8 & 38 \\
$\mathbf{2 0 0 7}$ & 1 & 0 & 40 & 0 & 0 & 0 & 0 & 0 & 0 \\
$\mathbf{2 0 0 8}$ & 5 & 2 & 42 & 7 & 1 & 0 & 20 & 12 & 9 \\
$\mathbf{2 0 0 9}$ & 19 & 7 & 50 & 23 & 3 & 1 & 172 & 16,5 & 42 \\
$\mathbf{2 0 1 0}$ & 74 & 28 & 78 & 13 & 3 & 0 & 123 & 8,75 & 24 \\
$\mathbf{2 0 1 1}$ & 0 & 0 & 0 & 0 & 0 & 0 & 0 & 0 & 0 \\
$\mathbf{2 0 1 2}$ & 43 & 16 & 94 & 11 & 2 & 0 & 93 & 11 & 20 \\
$\mathbf{2 0 1 3}$ & 8 & 3 & 97 & 23 & 3 & 0 & 70 & 45,5 & 29 \\
$\mathbf{2 0 1 4}$ & 7 & 3 & 100 & 11 & 2 & 1 & 65 & 1,5 & 24 \\
\hline
\end{tabular}

\subsection{Floods and large wood recruitment and mobility}

In order to determine the impact of floods (magnitude and type) on the recruitment and transport of large wood, the number of samples having the same $Y_{R}\left(N_{Y R}\right)$ and the same $Y_{A}$ $\left(\mathrm{N}_{\mathrm{YA}}\right)$ are plotted against the annual maximum discharge for the period 1993 to 2014 (Figure 4). Spring floods with ice-breakup are indicated with a distinct symbol. Although the two largest peaks of $Y_{R}$ occurred at discharge values higher than $400 \mathrm{~m}^{3} / \mathrm{s}$, large discharges do not systematically lead to high recruitment values (Figure 4A). At the same time, low discharge could recruit relatively high numbers of LW, especially in combination with major ice breakup (1993, 1996, 1998, 2003, 2009 and 2012). Together, these low discharge years account for more than $22 \%$ of the recovered samples, while the years with large floods (20; 50 and 100 years recurrence in 2004, 2008, 2011 and 2010) represent more than $37 \%$ of the trees sampled in the raft (Figure 4A). Figure 4B shows the frequency in years of accumulation in the raft $\left(\mathrm{Y}_{\mathrm{A}}\right)$ in relation to the maximum annual flows. The years 2009, 2010 and 2012 have produced and transported several LW pieces, while the high flow of 2011 only produced a few ones (Figure 5A), but appears to have produced a 
number of LWs (Figure 4B). This highlights the influence of two successive floods on wood transport and availability.
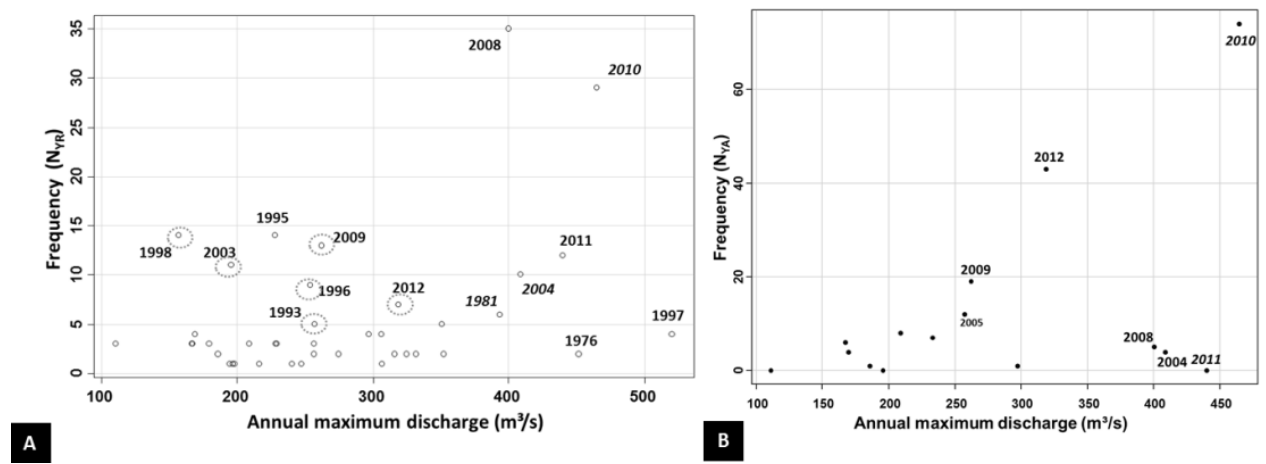

Fig. 4. A) Large wood mortality $\left(\mathrm{N}_{\mathrm{YR}}\right)$ (dashed circles indicates years with important ice break-up events) and; B) Year of accumulation in the SJR raft $\left(\mathrm{N}_{\mathrm{YA}}\right)$ in relation with annual maximum discharge.

A comparison between the number of samples recruited per year $\left(\mathrm{N}_{\mathrm{YR}}\right)$ with the number of samples accumulated in the raft per year $\left(\mathrm{N}_{\mathrm{YA}}\right)$ helps to determine the tendency of a flood to recruit large wood (when $\mathrm{N}_{\mathrm{YR}}>\mathrm{N}_{\mathrm{YA}}$ ), to remobilize large wood already transiting in the active channel (when $\mathrm{N}_{\mathrm{YR}}<\mathrm{N}_{\mathrm{YA}}$ ) or to be a mix of both phenomenon (when $\mathrm{N}_{\mathrm{YR}} \sim \mathrm{N}_{\mathrm{YA}}$ ) providing a typology of floods in terms of wood transport and recruitment. For the period with inter-annual data from 2000 to 2014, 6 floods (40\%) provided a mix of both recruitment of LWs and remobilization of LW stored in the active channel, four floods (27\%) had higher recruitment than transport to the raft, two floods $(13 \%)$ had less recruitment than mobility of LWs in the active channel, and finally three floods with ice breakup (20\%) had a high recruitment (2003), but mainly transported a large quantity of LW already dead in the active channel (2009 and 2012) (Figure 5).

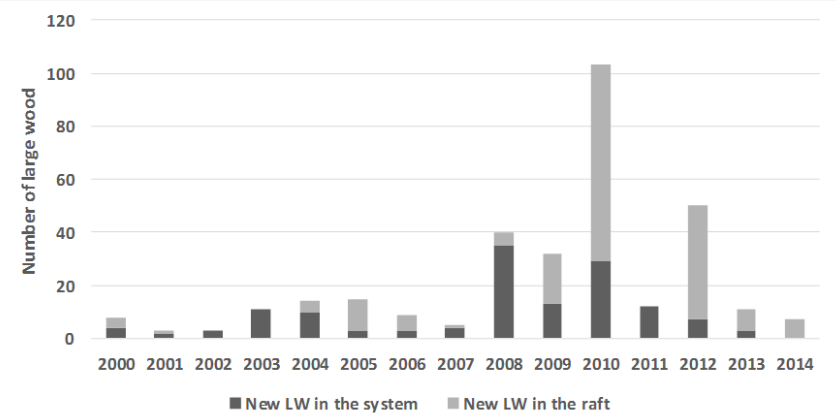

\begin{tabular}{|c|c|c|c|c|c|c|c|c|c|c|c|c|c|c|c|}
\hline Year & 2000 & 2001 & 2002 & 2003 & 2004 & 2005 & 2006 & 2007 & 2008 & 2009 & 2010 & 2011 & 2012 & 2013 & 2014 \\
\hline $\begin{array}{l}\text { Type of } \\
\text { flood }\end{array}$ & $\stackrel{x}{\Sigma}$ & $\stackrel{\times}{\Sigma}$ & $\begin{array}{l}\frac{}{\circ} \\
\frac{0}{0} \\
\frac{\pi}{0} \\
\frac{0}{2}\end{array}$ & 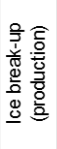 & 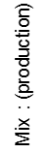 & 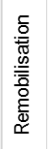 & 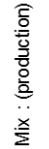 & $\begin{array}{l}\frac{}{\overline{0}} \\
\frac{\overline{0}}{0} \\
\frac{0}{2}\end{array}$ & $\begin{array}{l}\text { 흠 } \\
\text { 음 } \\
\text { 음 }\end{array}$ & 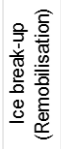 & 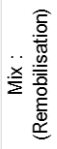 & 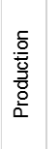 & 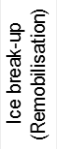 & 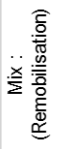 & 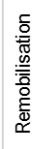 \\
\hline
\end{tabular}

Fig. 5. Number of large wood recruited per year (new in the system), number of large wood transported in the raft per year (new LW in the raft) and flood type in relation to the LW dynamics. 


\section{Discussion}

\subsection{Residence time}

Dendrochronological crossdating allowed us to determine whether there were key years or cycles in the production of LW in the SJR. This unique analysis could be realized through the combination of dendrochronology, geomorphology and hydroclimatology. In most rivers, transported LW are evacuated from the river system and it is very difficult to estimate residence time so that residence time values are scarce. Residence time data $(\mathrm{n}=$ 69) on the Queet River (gravel-bed dynamic river such as the SJR) shows residence times ranging from one year to 1400 years, with an average of 84 years and a median of 19 years [4]. More recently, Jones and Daniels [16] have shown that on 108 spruce logs sampled in a post-fire context, the residence time in the system ranged from 5 to 132 years. However, these estimates are generally based only on LW in the active channel and not the fraction exported outside the system because of the technical difficulty of measuring the LW taken out of a river system [16]. These two studies provide residence time values that are larger than those reported for the SJR in this study. With a median residence time of 3 years, the dynamics of the LWs in the SJR appears very intense as the LWs transit outside the system is very rapid. Smaller residence time have also been reported by Jochner et al. [17] and MacVicar et al. [18]. Here, the small residence time values may suggest the importance of ice break-up events and of high return period floods that occur in the last 10 years in the SJR.

\subsection{Large wood flood typology}

Based on the data presented here and on the previous articles of this project $[10,11,12]$, we propose a flood typology according to their influence on LW transport and production dynamics. The first flood type is the erosive flood (Figure 6A), where the river recruits a large amount of LW, but with limited transport (intense but short-lived flooding). The second type is a LW transport flood (Figure 6B), characterized by significant remobilization of LW accumulated in the active channel of the river. These floods produce little wood, but can carry significant amounts of LW from upstream to downstream. The third type is the mix flood (Figure 6C), which recruits new LW through lateral channel migration and can also transport these new wood in the active channel, along with previously accumulated LW. Finally, for cold-climate environments, ice-breakup floods (Figure 6D), recruit few new LWs, but carry significant volumes accumulated in the active channel of the river [11].
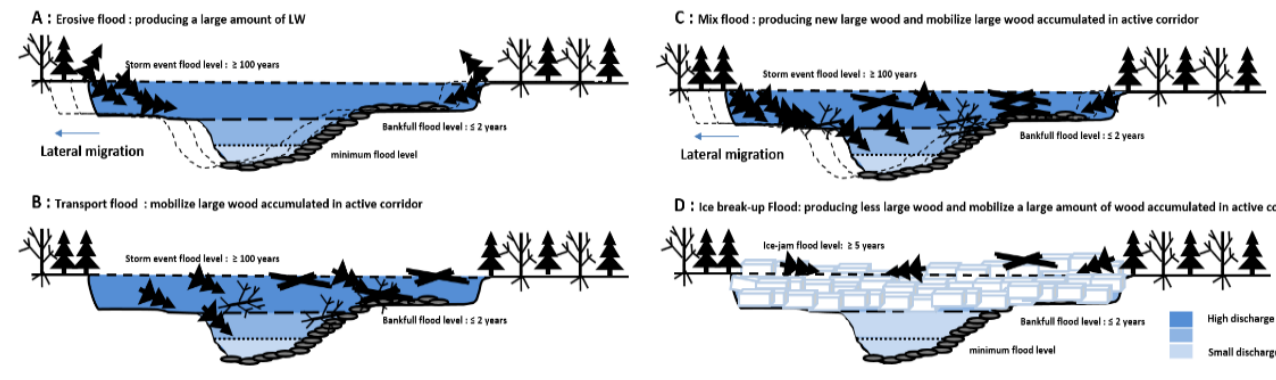

Fig. 6. Conceptual model of the four main types of flood depending on the influence on large wood dynamics in cold river. 


\section{Conclusion}

The SJR Raft is a natural trapping structure with high potential to monitor LW export from the catchment through time. The first important result of this paper is the very short median LW residence time combined with a large variability. With a median residence time of 3 years, the LW in the SJR is moved very rapidly from upstream to the end of the system into the SJR raft. With over $80 \%$ of the LW coming from the upstream portion, we can say that most LW pieces travel more than $30 \mathrm{~km}$ in less than 3 to 5 years. A second important contribution of this paper is the proposed typology of floods in relation with the dynamics of the LW in rivers of cold regions. The next step following our study would be to determine the origin of each tree, for example by biochemical analyzes or active and passive tags survey, in order to estimate the transit time and distance travelled for each tree and improve our knowledge of LW budget.

Financial support was provided by MITACS and Conseil de l'Eau du Nord de la Gaspésie, We thank Gilles-Marie Coulombe for his excellent assistance during fieldwork and Annabelle Mercier-Morache for preparation and assistance in sample analysis.

\section{References}

1. F.J. Triska, Verh. Internat. Verein Limnol. 22: 1876-1892 (1984)

2. E. McCall, Am Herit Invent Technol. Winter: 10-16 (1988)

3. F.J. Swanson, G.W. Lienkaemper, J.R. Sedell, U.S. For. Serv. Gen. Tech. Rep. PNW-56. (1976)

4. T. Hyatt, R. Naiman, Ecol Appl. 11: 191-202 (2001)

5. M.E. Harmon, J.F. Franklin, F.J. Swanson, P. Sollins, S.V. Gregory, J.D. Lattin, N.H. Anderson, S.P. Cline, N.G. Aumen, J.R. Sedell, G.W. Lienkaemper, K. Cromack, K.W. Cummins, Adv. Ecol. Res. 15: 133-302 (1986)

6. R.J. Naiman, E.V. Balian, K.K. Bartz, R.E., Bilby, J.J. Latterell, In Proceedings of the Symposium on The Ecology and Management of Dead Wood in Western Forests. USDA Forest Service, 181: 23-48 (2002)

7. E. Wohl, Earth-Sci. Rev. 123: 194-212. (2013)

8. A. A. Webb, W. D. Erskine, J Environ Manage. 68 (4): 329-341 (2003)

9. É. Boucher, Y. Bégin, D. Arseneault, Geomorphology. 108: 273-281 (2009)

10. M. Boivin, T. Buffin-bélanger, H. Piegay, Geomorphology 231: 270-280 (2015)

11. M. Boivin, T. Buffin-bélanger, H. Piegay, Geomorphology 279: 59-73 (2017a)

12. M. Boivin, T. Buffin-bélanger, H. Piegay, Earth Surf. Process. Landf 42: 2199-2213 (2017b)

13. F. Gennaretti, D. Arseneault, Y. Bégin, J. Ecol. 102: 367-380 (2014)

14. E. R. Cook, International Tree-Ring Data Bank, IGBP-PAGE/World Data Center for Paleoclimatology, NOAA/NCDC Paleoclimatology Pro-gram, Boulder, Colorado. (1994)

15. Centre d'expertise hydrique du Québec (CEHQ), Répertoire des Barrages Saint-Laurent-Sud-Est. MDDELCC, http://www.cehq.gouv.qc.ca/barrages, (2014)

16. T. A. Jones, L. D. Daniels, For. Ecol. Manage. 256 (10): 1751-1759 (2008)

17. M. Jochner, J. M. Turowski, A. Badoux, M. Stoffel, C. Rickli, Earth Surf. Dyn. Discuss. 3: 173$196(2015)$

18. B. J. MacVicar, H. Piégay, A. Henderson, F. Comiti, C. Oberlin, E. Pecorari, Earth Surf. Proc. Land. 34: 2031-2046 (2009) 